\title{
SISTER OF THE TYPE: THE FEMINIST COLLECTIVE IN GRANT ALLEN'S THE TYPE-WRITER GIRL
}

\author{
By S. Brooke Cameron
}

GRANT AlLEN's SHORT NOVEL THE TYPE-WRITER GIRL (1897) opens with a problem. In the first lines we are introduced to our narrator who, we are promptly told, is unemployed: "I was twenty-two and without employment. I would not say by this that I was without occupation. In the world in which we live, set with daisies and kingfishers and undeciphered faces of men and women, I doubt I could be at a loss for something to occupy me" (23; ch. 1). As the second half of this quotation suggests, our narrator is confident that this problem of employment is quite easy to solve, for all around is a world teeming with life, and as we learn by the start of the next paragraph, our narrator does indeed have an occupation, something to fill his/her time. Our narrator is a storyteller: "I cannot choose but wonder who each is, and why he is here. For one after another I invent a story. It may not be the true story, but at least it amuses me" (23; ch. 1). So the real problem, beyond the question of employment, emerges as a question of narrative subject. Who is this narrator, the subject of this first-person story? We do not even know if our narrator is male or female. It is as if he/she is lost amidst that sea of "undeciphered faces of men and women." Connected to this problem of subject is also the question of form. The first-person point of view would suggest an autobiographical narrative. Yet any expectations of an autobiographical account are immediately undermined in chapter two when we learn that our narrator is named "Juliet Appleton." This narrative subject does not match the novel's signed author, "Olive Pratt Rayner." So we are again left with questions: what kind of narrative is this, who is the real subject of this story, what is the form of this narrative, and does our narrator find employment?

Leah Price has argued that this problem with the authorial subject is compounded by the novel's repeated emphasis on bonds between women. In "Grant Allen's Impersonal Secretaries: Rereading The Type-Writer Girl," she explains how Allen draws on the autobiographical form to claim psychological depth and autonomy for his protagonist. Price's argument draws on a model of autobiography advanced by critics such as Philippe Lejeune, which describes the conventional expectation of the cohesive subject who narrates and thus 
effectively writes himself/herself into being. However, Price adds, The Type-Writer Girl's subplot, focusing on bonds between women, obscures the singular, authorial subject whom readers typically associate with this narrative form. In particular, Juliet's relationship with Elsie, another typist, leaves readers uncertain as to which "type-writer girl" the novel's title refers. Indeed, the autobiographical subject is even further obscured by the fact that the novel itself is signed with a feminine pseudonym that is not the name of either woman in the story. ${ }^{1}$ The text thereby refuses to deliver a singular and unified authorial subject, the real type-writer girl. ${ }^{2}$

Despite such complications, it is critical that we read The Type-Writer Girl as autobiography, for the novel clearly invokes and then plays with many of the conventions associated with this narrative form. For example, the text not only employs a first person perspective, but the plot itself centers on a story of self inquiry and self formation typical to the autobiographical genre. In addition, the novel's title, which emphasizes typewriting, invites readers to assume a certain equivalence among the narrator who tells the story, the narrated subject of the story, and the real author who signs the story. In other words, we are encouraged to assume that the subject who signs the cover must be one and the same with the narrator who recounts her experience as "The Type-Writer Girl." Nonetheless, Price is right that there is a persistent ambiguity as to the authorial subject or the real type-writer girl. The problem is compounded by the story's shift from self-discovery, or the formation of a coherent subject, to bonds between women and a sort of feminist community.

In this essay I will take a closer look at the problem of the authorial subject in The Type-Writer Girl by reading the novel within the context of Grant Allen's extended writings on economics and gender. Such a contextual reading will help us to see how the novel draws on this narrative genre as part of its experiment in a new theory of female subjectivity as relational, not autonomous. Recent scholars such as Heather Atchison, Lyssa Randolph, Sabine Ernst, and William Greenslade and Terence Rodgers have demonstrated the need to think of Allen as a polymath whose work interweaves a wide variety of disciplinary threads, including economics, biology, evolutionary science, and feminism. With this body of scholarship in mind, I read The Type-Writer Girl's opening scene as clearly promising a narrative interested in the intersections between economics and gender. What is more, the novel describes Juliet's search for employment in terms of adaptation, a move that clearly reminds us of Allen's devotion to Herbert Spencer's work on social evolution. Upon considering Allen's other writings, we can see how The Type-Writer Girl links together and implicitly compares models of social and narrative adaptation. Just as she struggles to adapt to the gendered marketplace, Juliet also struggles to find and fit into the appropriate narrative structure with which to tell her story. It is important to note that Allen himself was rather conservative when it came to women's role in social evolution. However, there is a way in which his own theories and, hence, narrative subject exceed his control. Specifically, his interdisciplinary combination of feminism and economics suggests a new way of thinking about gender as a social and thus a collaborative formation. By extension, then, we must not think of The Type-Writer Girl as a failed autobiography but instead as a narrative that begins and ends with the social subject. Juliet's tale of self inquiry and self formation culminates in bonds between women. As a result, she requires a new autobiographical narrative that balances the individual and the female collective.

To appreciate The Type-Writer Girl's innovations in form, we must first look at the novel's plot, for it is here where we can locate the formation of the feminist subject, the 
catalyst of this new narrative. The Type-Writer Girl traces a significant shift in focus from a romantic plot to an economic plot and a corresponding shift from the individual to the feminist collective. This shift in turn contains many echoes of Allen's writings on Social Darwinism and progressive adaptation. By reading Juliet's story in the context of Allen's other writings we can also appreciate the unique work of the novel's narrative experiment, its effort to think through narrative representation. In particular, The Type-Writer Girl asks how to represent the individual who identifies with the social and, specifically, feminist community. The result is a story of social adaptation, both gendered and economic.

The second half of this essay looks at technologies of self production, including both autobiography and typewriters. As Price notes, the novel is signed by Rayner, not Appleton, and as a result the novel does not suggest a reproduction of Juliet, the girl behind the keys; instead, we have another "type-writer girl," a label which could easily apply to any of the female characters in the novel. The typewriter is a particularly effective symbol for this study: it is both a means of reproduction of texts as well as the means by which Juliet reproduces herself, her story. Does this failure to produce a coherent autobiographical subject parallel the ways in which technologies of mechanical production, like the typewriter, erase the subject? As I will show, this is not a problem of reproducing an autonomous self; rather, this narrative reproduces the story of gender and labor consciousness and, ultimately, the feminist collective. It is important, then, that Juliet's tale is titled "The Type-Writer Girl," for this title holds in uneasy but illuminating tension the individual girl and her relationship with women's labor.

\section{Part 1: the Feminist Collective}

DURING THE 1880S AND 1890s, Grant Allen wrote several works devoted to the New Woman debates. He is probably best remembered for his first New Woman novel, The Woman Who Did (1895), which created an absolute scandal due to its unabashed advocacy of free love and women's sexual liberation. His second New Woman novel, The Type-Writer Girl (1897), is no less radical in its representation of the fin-de-siècle woman question. But what makes this latter work different from the first is its effort to explore the woman question through economics and technologies of production. His outspoken heroine, Juliet Appleton, boldly navigates the world of economics, including the competitive marketplace of female typists and an anarchist commune on the fringe of society. Readers first meet Juliet as she leaves Girton College "in search of adventures" and, more importantly, in search of love in the form of "some youthful St. George in celestial armour" (26; ch. 1). The novel sets up what readers expect will be a romance plot culminating in love and the heterosexual union. However, our heroine quickly abandons the romance plot following her first, intensely disappointing encounter with the competitive marketplace. During an interview for a typist position, the employer, Mr. Fingleman, looks her over "as if he were buying a horse," making Juliet feel "like a Circassian in an Arab slave-market" (31; ch. 2). ${ }^{3}$ Despite this oppressive and objectifying gaze, Juliet wonders how she might "adapt [herself] to [her] environment" and thereby "[fulfill] the whole gospel of Darwinism" (32). Hence, the first half of her story, entirely preoccupied with this struggle to adapt to the marketplace, suggests that economic forces disrupt if not entirely displace romance.

With Juliet's first interview, The Type-Writer Girl foregrounds its narrative investment in the intersections between economics and social evolution. ${ }^{4}$ This investment is the result of 
Allen's devotion to Herbert Spencer's theory of social adaptation and progress. ${ }^{5}$ Allen was particularly interested in Spencer's discussion of purposive adaptation through functionally suitable traits. Perhaps one of Spencer's best known examples of this concept is his discussion of the blacksmith's arm:

as surely as a blacksmith's arm grows large, and the skin of a labourer's hand thick; as surely as the eye tends to become long-sighted in the sailor, and short-sighted in the student; as surely as the blind attain a more delicate sense of touch; as surely as a clerk acquires rapidity in writing and calculation; as surely as the musician learns to detect an error of a semitone amidst what seems to others a very babel of sounds; as surely as a passion grows by indulgence and diminishes when restrained; as surely as a disregarded conscience becomes inert, and one that is obeyed active; as surely as there is any efficacy in educational culture, or any meaning in such terms in habit, custom, practice; - so surely must the human faculties be moulded into complete fitness for the social state; so surely must the things we call evil and immorality disappear; so surely must man become perfect.

(Social Statistics 65)

As suggested by the last line, "so surely must man become perfect," Spencer absolutely believes that adaptation and, by extension, the social organism itself tend towards perfection. ${ }^{6}$ His confidence is the result of his unique model of social evolution, or "Social Darwinism," as described in works like Descriptive Sociology (1873-81), Principles of Sociology (187696), and "Progress: Its Laws and Causes" (1857). Spencer uses the analogy of the biological organism to explain what he characterizes as the progressive evolution of the social body and its composite parts. As with the biological organism, the evolution of the social body is marked by a trend toward complexity, with its composite parts performing increasingly specialized yet interdependent functions. For example, in his struggle for survival, the blacksmith (or composite part), hones his particular talent, in this case his muscular arm, so that he can be all the more productive and thus contribute to the increasingly complex society (social body). Interestingly, this process of adaptation is also marked by a distinct trend toward sociality. The individual's conscience is reactivated and obeyed, and human facilities are moulded to ensure "complete fitness for the social state," ready to contribute to progressive evolution.

Informed by Spencer's theory, The Type-Writer Girl explores how alternate economic arrangements such as a cooperative community might counter the harmful effects of the competitive marketplace. When Juliet overhears two men discussing the anarchist commune on the outskirts of town, she idealizes the "band of brothers" (36; ch. 3$)$ who "cultivate in common; each member of the community receives food and clothes; and at the end of the week, if any surplus remain, they divide it between them by way of pocket-money" (37). ${ }^{7}$ Juliet then flees the world of competitive labor and joins the commune, hoping she will finally be allowed to perfect her talent and thus contribute to the social body. However, early into her stay, Juliet realizes that this commune does not present the opportunity for purposive adaptation. Members are required to perform tasks incompatible with their specific talents. As Juliet observes, these laborers "toiled hard and inefficiently," and yet "[i]n the sweat of their brow they did very little" (54; ch. 7). When Juliet asks Rothenberg, one of the leaders, how the community would respond to a member who refused to work, he hesitantly explains that "we would be compelled to call in . . the State . . to eject him." Disgusted with such "[c]oercive practices" (54), Juliet realizes that the anarchists are no better than the competitive capitalists from whom she fled. Both societies demand that laborers submit to 
the tyranny of those who control labor. Feeling herself to be "too individual, too anarchic for the anarchists," she flees the commune to "set [her] face sternly towards civilization, despotism, and the flesh-pots of Egypt" (58).

Yet Juliet's brief hiatus in the anarchist commune is not a waste, for this experience encourages her to imagine an alternative community wherein all members are able to purposely contribute to the social body. It is this failed attempt to participate in some kind of community that causes her second encounter with the world of competitive labor to give way to gender consciousness. Early in the course of her second search for employment, Juliet realizes that she is competing with specifically "female" typists. She even emphasizes the gendered aspect of this competition when she describes her appreciation for an advertisement that respectfully refers to "Lady" typists as opposed to female type-writers: "I liked that advertisement. My theory is that a type-writer girl should call herself a type-writer girl; but that an advertiser should do her the courtesy to speak of her as a Lady Type-writer, or something of the sort: certainly not as a (parenthetical) female" $(75 ;$ ch. 11$){ }^{8}$ What Juliet thus approves of is a revised advertisement which calls attention to, rather than obfuscates (through marginal, parenthetical reference), the gender of the applicant.

Juliet's insistence upon the label "Lady" marks the emergence of her genderconsciousness, her awareness of her own position in the competition among, specifically, women typists. However, her preference for the title "Lady" immediately suggests a class distinction, aligning the female typist with an upper-class woman. Juliet wishes that employers, by addressing typist as "ladies," both recognize and respect the gendered dynamic of this labor; yet this respect must elevate and thus distinguish the female typist from her working-class sisters. Juliet clearly wishes that women's work as typists be distinguished from those other forms of public and, more specifically, working-class labor which many Victorian women already performed. At this point, her growing feminist consciousness is limited by class. ${ }^{9}$

However, Juliet's limited sympathy toward women's work does not last. With this turn to gender consciousness, the novel marks a significant shift in the narrative's trajectory. Our heroine now has a whole new set of priorities, which in turn demands a new plot. Early into this second encounter with the marketplace, Juliet not only finds herself identifying with other women, but she also takes it upon herself to secure a poor and working-class women's well-being. The novel again foregrounds the primary importance of the economic plot, but by this point, the female collective supplants the individual as the narrative subject. Upon leaving a successful interview, Juliet feels overcome with compassion for another typist, a girl "less strong than [herself], coming down from the office with a most dejected countenance" (75; ch. 11). Juliet recognizes immediately that this woman has failed in her application for the position, which in turn causes Juliet to ponder, "if this were the struggle for life, it made my heart ache (for her sake) to think I must engage in it" (75). Juliet is careful to qualify, in the parenthesis of her thoughts, how she "aches" from the emotional pain she experiences for the "sake" of another. Her pain is the product of her effort to imagine another human being's suffering. ${ }^{10}$ This series of events echoes Allen's notion that women, more than men, are defined by their sociality. So it is not entirely surprising that Juliet's story would quickly morph into a story about a female consciousness, her identification with another female victim of the gendered marketplace.

As illustrated by his first New Woman novel, The Woman Who Did, Allen is an outspoken advocate of women's sexual liberation and freedom of choice in selecting partners and mating 
conditions. However, his vision of choice is not without its limits. The ideal female individual, a kind of biological type, recognizes that her sexual selection, and subsequent reproduction, ultimately serves the larger social body. No article better illustrates Allen's position on women's reproductive duty than "Woman's Place in Nature" (1889). In this article, Allen rejects Lester Frank Ward's argument that "woman is the race" (qtd. in "Woman's Place in Nature" 167). Whereas Ward attributes agency to women, Allen writes that woman is "not even half the race at present, but rather a part of it told specially off for the continuance of the species. . . She is the sex sacrificed to reproductive necessities" (167). ${ }^{11}$ Allen sees the female body as the passive vessel of natural evolution. Clearly, in Allen's opinion, this vessel lacks agency. Women do not influence evolution; rather, evolution exercises its plan through the female's body. Thus, Allen holds fast to the idea that all women, even New Women, are bound by nature to the social body, destined to bear children and thus perpetuate the evolution of the species. ${ }^{12}$

What is odd about Juliet, however, is precisely her consciousness and subsequent agency. She is not a passive vessel of nature. Rather, her turn to social responsibility depends upon her realization that women's fates are tied together and hence that women's perfected adaptation depends upon cooperation. Later when she again sees Elsie, the woman whom she "had supplanted in the struggle for existence" (93; ch. 15), Juliet immediately assumes responsibility for her competitor's fate and helps her find employment. Empathetic identification therefore inspires Juliet to form a cooperative alliance with her fellow female worker. Juliet no longer recognizes herself in competition with other women; instead, her compassionate identification with the other woman inspires her to collaborate with women, melding together her own self-interest with that of the female community. ${ }^{13}$

Juliet's conscious decision to embrace the social body, to assume responsibility for her fellow female typist, is significant insofar as it suggests that the female individual is an active agent shaping social - not natural - forces. This qualification takes on added significance when we remember Allen's source for evolutionary science: Herbert Spencer. Indeed, the tension between nature and nurture, so to speak, is inherent in Spencer's own account of the supposed natural evolution of the social body. Take for example the analogy of the blacksmith's arm. Even in this example, Spencer's version of social evolution admits that increased complexity also tends towards increased sociality. The body's composite parts, or individuals, must by necessity recognize their social interdependence and subsequent need for cooperation. Though the blacksmith's arm is perfectly formed for his specific labor, his ears have not evolved in such a manner as would befit musical tasks. Thus, for music, the blacksmith must look to the musician, just as the musician must consult the blacksmith on matters of ironwork. Individuals become increasingly specialized, and this specialization, in turn, stimulates interdependency and thus social cooperation. In fact, cooperation is vital to the health of the whole organism. In his 1860 essay "The Social Organism," Spencer explains how "Simple communities, like simple creatures, have so little mutual dependence of parts, that mutilation or subdivision causes but little inconvenience; but from complex communities, as from complex creatures, you cannot remove any considerable organ without producing great disturbance or death of the rest" (273).

Juliet's female-female bond clearly echoes the Spencerian account of the sociable individual. More importantly, her subsequent adoption of Elsie, the other typewriter girl, suggests how cooperative complexity is social, not biological. Juliet recognizes how she supplanted Elsie in the struggle for employment, and in this same moment, she understands 
that women's fates are linked together in the competition for survival in the marketplace. Following this revelation, Juliet shifts from the competitive impulse and assumes social responsibility for her fellow female laborer. The bond between the two women is so strong that Juliet refers to Elsie as her "adopted daughter." Indeed, Elsie's "helplessness and incompetence inspire[s] in [Juliet] at last that sense of motherliness which we women love" (94; ch. 11). Juliet's subsequent adoption of Elsie thereby reminds one of what Allen characterizes as the maternal bond linking the female with the social body. However, this maternal bond is not an expression of natural forces, the innate drive toward biological reproduction; rather, this maternal bond is a social response to social circumstances, specifically the gender conditions of women's labor.

Juliet's bond with Elsie also marks a significant shift in her feminist consciousness and, particularly, her former classist approach to women's work. We recall her earlier preference for the label "Lady Type-writer" (75; ch. 11). However, after befriending Elsie, Juliet embraces a new feminist consciousness. She no longer privileges upper- or middle-class women; now she takes all women, including those who are poor and working class, as her site of sympathetic identification. She recognizes that her own relationship to labor is limited by all of women's employment opportunities. What is more, Juliet's bond with Elsie also suggests how these social norms or relationships are malleable. Juliet realizes that it is the gendered marketplace that has placed her in competition with this unfortunate woman, and through the maternal bond, both women redefine women's relationships as cooperative. ${ }^{14}$

It is this story of the female collective that henceforth dominates the plot of The TypeWriter Girl. In the last third of the novel, the romance narrative resurfaces only to be displaced, once again, by the feminist collective. This final clash in plots serves as a reminder of the interdependent relationship between the female individual and the social body. Juliet has met and fallen in love with her second employer, dubbed "Romeo." When Juliet pursues him and forces him to respond to her, he confesses that he is already engaged to Michaela (called "Meta" by others). Juliet eventually feels sorry for Michaela and tells Romeo to return to his slighted lover. As Juliet explains to him, Michaela "has grown up with your love inextricably twined by rootlets and tendrils through the fiber of her being; to tear it away now were to tear her very heart out"(132; ch. 21). In Michaela's world, a woman's happiness is entirely dependent upon the love and thus approval of a man, a husband. Juliet identifies with Michaela's suffering and therefore feels guilty about displacing yet another woman in the struggle for survival. Even as she breaks the news to Romeo, Juliet is preoccupied with thoughts of Michaela. She hears, echoing in her mind, and then repeats, Michaela's desperate plea, "the years must count" (128; ch. 20 and 132; ch. 21). Emotionally aligned with her female rival, Juliet demands that Romeo honor Michaela's investment, her hard work in loving him for five years. Again, Juliet's sympathetic identification extends beyond the specific woman to some larger notion of female community. In the case of Michaela, Juliet decides that she is "fighting the common battle of womanhood. If [she] were to turn traitor now, [she] should turn traitor to whatever [she] had within [her] best worth calling a conviction" (133-34; ch. 21). With this female-female bond in mind, the narrator once again sacrifices her own story, her love plot, in order to tell a new narrative about the feminist collective.

But the novel does not conclude with this act of sacrificed love; instead, the novel ends with Juliet's financial debt, a symbol that once again reminds us of the intersections between economics and gender. In the closing lines of the text, Juliet procures a loan of "two hundred 
lire" from Michaela (139; ch. 21). Juliet needs this money so that she can return home and resume her work as a typist. This debt circulates as a symbol that functions on two levels. On one level, her debt represents her tie to the economic body. As Spencer showed us, the individual must adapt to and thereby contribute to the social organism's complex and interdependent web of production. On a second level, her financial debt also suggests the influence of the social body upon the individual. Juliet's debt therefore reminds us of the tension within the Spencerian model wherein the individual needs and is therefore, on some level, indebted to the larger social network for his/her very existence. By the end of The Type-Writer Girl, it becomes difficult even to imagine the individual as independent of the social body. It is not surprising, then, that the novel's final look at economic individualism returns us yet again to a social variation of the maternal bond. When Michaela asks if this amount is enough, Juliet answers, "[y]es my child. . . . If I work my fingers to the bone you shall have it back" (139; ch. 21). Again, by calling Michaela "child," Juliet assumes the position of mother to another woman. In an interesting twist, Michaela as the adopted child replaces any biological children Juliet might have had with Romeo. And Juliet's debt emphasizes that this maternal bond is economic, implicating that larger social fabric of work and productive contribution. ${ }^{15}$ And even if it destroys her body - her physical subjectivity Juliet will work on behalf of and thus "pay" this woman, and the womankind she represents.

\section{Part 2: Technologies of the Self}

AS SUGGESTED BY THE NOVEL'S TITLE, technology is at the heart of this story of a modern "type-writer girl." We have technologies of mechanical reproduction in the form of the typewriter, but we also have technologies of self-production in the form of a fictional autobiography. From the start, readers are meant to recognize this narrative as drawing on many of the conventions of autobiography, particularly the interconnectedness of the multiple narrative "I"s. In Reading Autobiography, Sidonie Smith and Julia Watson outline many of the components which comprise the autobiographical act. Some of the most important features, replicated in The Type-Writer Girl, focus on both the site and subject of the narrative. Regarding the former, the subject's narrative is located within a specific geographical and historical location, and so the subject's account must make sense or "seem 'credible' and 'real"' within this site (Smith and Watson 56). In the case of The Type-Writer Girl, the narrative location is late-Victorian England, which witnessed massive shifts in the urban workforce. Advances in technology, such as the typewriter, translated into an explosion in new and skilled clerical positions. The middle-class and, more importantly, independentminded New Women, eager for respectable employment and economic self-sufficiency, flocked to these jobs. Juliet's narrative about professional and gendered self-discovery is exactly in keeping with this movement and thus true to its period. ${ }^{16}$

Even more important is the novel's clear awareness of the intertwined and multiple uses of "I" that comprise the autobiographical narrative. As Smith and Watson explain, the autobiographical "I" is much more complicated than "a speaker or narrator who refers to herself" (58); rather, there is the real or historical "I" (typically denoted by the signature on the text), the narrating "I" (the agent who tells the story), the narrated "I" (the subject of the story), and the ideological "I" (the I as produced via multiple social sites / contestations, expectations, etc.). The Type-Writer Girl is clearly aware of and also wants to complicate the way that we think about these multiple uses of the autobiographical "I." The first-person 
point of view immediately tells readers that we have an intimate and personal account by a narrator who takes herself and her life as the subject of the story, connecting the narrating and narrated "I." And the feminine signature upon the novel's cover would, at first glance, suggest a further link with the historical "I." However, the signature and the subject's name do not match. We can only make sense of this seeming disjunction between signature and subject upon further investigation of the narrative's investment in the ideological "I." This latter "I," Smith and Watson explain, is a product of social interdependency, or "relationality": "The self-inquiry and self-knowing of many autobiographical acts is relational, routed through others," and "this concept of relationality, implying that one's story is bound up with that of another, suggests that the boundaries of an 'I' are often shifting and flexible" (64). As if anticipating the Smith and Watson theory, The Type-Writer Girl recounts Juliet's selfdiscovery or self-formation as a process dependent upon her bond with fellow women - that is, the female collective. As I will show, her narrative requires a new autobiographical form which keeps in play this relational "I," the social dimension of the subject.

By refusing to name a specific girl, the novel's title invites readers to think about the social formation of the autobiographical subject. Readers are instead encouraged to remember how Juliet's formation is a product of her self-identification with other type-writer girls like her. However, for other critics, like Leah Price, this ambiguous title reminds us of the relationship between and the problems with technology and authorial specificity. Price argues that Allen fails to give his characters depth and that their superficiality makes them easily reducible to typewriters, empty and impersonal machines reproducing narratives. For critics such as Christopher Keep, Victoria Olwell, and Jennifer Wicke, this is a problem that frequently accompanies representations of the female typist. As these scholars point out, the typewriter, with its standardized font, erases all trace of the author's original presence, including such idiosyncratic markers as penmanship and signature. ${ }^{17}$ What is more, the typist's own work reproducing texts is likewise invisible. There is nothing distinct about her standardized type set. Indeed, as Keep records, oftentimes female typists were called "typewriters," a label that conflates the human being with the technologies of mechanical reproduction. ${ }^{18}$ The typewriter seems both the perfect symbol and even title for a supposedly autobiographical narrative lacking any kind of authorial specificity.

However, this problem of the authorial subject makes sense once we remember the novel's investment in the feminist collective. Whereas Price argues that Allen's characters are superficial, I claim that Juliet's social consciousness demonstrates a certain complexity of character. Commitment to the female collective can, in turn, explain the title's play on "typewriting" as a reference both to subject and to labor. By including the adjective "type-writer" in its title, the novel reminds us that this is a subject whose identity is inextricably tied to the conditions of production. Indeed, the typewriter is the perfect symbol for this social subject. The typewriter (the person who types) mediates between the narrator (who dictates) and the audience (who then reads the typewritten word). ${ }^{19}$ Therefore, as a typist, Juliet is already thrust into an intermediate space, caught between other individuals. And her typewriter, as a means of mechanical reproduction, also reminds us of her maternal labor of reproducing. As Mary Ann Doane explains, in “Technophilia: Technology, Representation, and the Feminine," the fin-de-siècle typewriter, with its capacity for multiple and indistinguishable reproductions, displaces the idea of the particular or original subject. Using psychoanalytic theory, Doane describes how the female typist thereby offers conflicting possibilities. On the one hand, the transformation of the maternal body into the machine promises to alleviate masculine 
anxiety regarding the unfathomable and castrating female. On the other hand, the masculine subject needs the maternal body in order to establish sexual differentiation and a notion of subjectivity rooted in some kind of origin. These two modes of reproduction, the mechanical and the biological, coexist "in a relation that is a curious imbrication of dependence and antagonism" (167). But men's anxiety aside, the new mechanical reproduction perfectly captures what Juliet experiences as an uneasy tension between the social and the individual. Juliet's problem, by the novel's end, is not that she needs to find some mode of autonomous self-expression, but rather that she must find some way to contribute to and thus reproduce the female collective. This feminist collective requires a new narrative that can balance both the group and the individual. This story of and by a typewriter is an attempt to answer this narrative problem.

From the start, Juliet's effort to make her story fit within familiar plotlines reminds us of the social individual and purposive adaptation. In the novel's opening chapter, she imagines herself as a heroine in search of her romance plot; she needs a Romeo to play opposite her Juliet. Indeed, Juliet is so committed to this plot that, when she does meet her love interest, she dubs him Romeo, and at no time does she show any interest in revealing his identity. We are also reminded of the scene when Juliet first meets Meta, whom she names "Michaela" in reference to the play Carmen. This nick-name is ironic, for in the play Michaela and Carmen will compete for the same lover, and Juliet will soon discover that she, too, is in competition with Meta / Michaela. ${ }^{20}$ Such foreshowing begs the question whether character determines the plot, or if the character is in fact overdetermined by set narratives. In the case of Michaela and Juliet, their names alone place them within recognizably tragic stories, trajectories of heartbreak and unresolved love. However, in keeping with his other works, Allen's novel preserves a certain space for the individual's productive contribution. Juliet recognizes that she cannot fit within the romance plot. Though she does not technically adapt to the heterosexual love story, she is able to rewrite this plot into a new story of love between women.

Drawing upon conventions associated with autobiography, our heroine also reminds us that narratives, even the most personal stories, are still social formations. It is even more impressive to note that, with this gesture, The Type-Writer Girl anticipates late twentieth-century scholarship on autobiography as social collaboration. Recent scholars of autobiography, such as Paul John Eakin, have long argued that the autobiographical subject is produced through social structures and relationships. As Eakin explains, the idea of an autobiographical subject who writes, says, or creates himself/herself is "an illusion of selfdetermination"; instead, "all identity is relational," and thus "the definition of autobiography, and its history as well, must be stretched to reflect the kinds of self-writing in which relational identity is characteristically displayed" (43-44). ${ }^{21}$ Emphasizing the cooperative above the singular or competitive, The Type-Writer Girl is aware of this relational subject and its demand for a new narrative structure. Juliet doesn't see herself as an autonomous entity; rather, her actions are informed by a sense of responsibility to the social group, the feminist collective. Her story of gender consciousness and the formation of a feminist identity thus gives way to a new autobiographical narrative, one that both describes and reenacts women's relationships with each other. ${ }^{22}$

With this emphasis on the social subject, The Type-Writer Girl thus negates the problem of the signature. Instead, the text invokes and prioritizes the multitude of different "I"s associated with the autobiographical narrative. Ultimately, the life narrative focuses on the feminist collective and not the autonomous or real authorial "I." Hence, the "autobiographical 
pact" - wherein the narrator and signature are one and the same - is supplanted by the ideological or relational "I." In their definition of this latter "I," Smith and Watson write: "The routing of a self known through its relational others undermines the understanding of life narrative as a bounded story of the unique, individuated narrating subject"; rather, "no 'I' speaks except as and through its others" (67). Juliet's story and, by extension, her subjectivity is not bounded but instead forms in relation to and is eventually inextricably linked with those other women with whom she identifies. We must recognize this novel as drawing upon conventions of autobiography only to tell the story of Juliet as that of ALL the other typewriter girls.

Even more impressive, however, is the novel's use of technology as a way to draw attention to the inclusiveness of this narrative of selfhood. In "The Work of Art in the Age of Mechanical Reproduction," Walter Benjamin reminds us how art in the age of capitalism must utilize and also reflect upon technologies of mechanical production. His account of modern art traces that historical shift away from the auratic theory of art to a new understanding of modern art as socially engaged. As he explains, because pre-capitalist art objects were denoted by their rarity, enjoyment of such works was limited to a small group of privileged individuals. Those able to access the work of art would, through a kind of cultic ritual of consumption, reaffirm the work's "aura," that core value which then magically reaffirms both the art work's rarity and the group's elite status. But in the age of capitalism, it is possible to mechanically reproduce and distribute art widely. While the new technologies of mechanical reproduction effectively erase art's auratic value, they also enable a new relationship between the work of art and its cultural context. The new, modern work of art is self-conscious of its participation in mass culture. Its mechanical reproduction and mass circulation do not threaten but rather contribute to the work's identity as art. In a move that anticipates Benjamin's theory, Juliet's narrative takes on the role of a mass-produced art. When read with reference to the title The Type-Writer Girl, the novel's conclusion realigns Juliet with the category of women's labor, and at the same time it also aligns her with technologies of mechanical reproduction. Yet her typewriting does not erase her specificity, her aura; rather it foregrounds her status as a cultural subject, an entity that is produced and reproduces the social body, particularly the gendered conditions of labor.

As a self-conscious agent of purposive adaptation, Juliet is also able to craft a narrative that calls attention to and even mimics the technologies of self-production. Indeed, her repeated reference to familiar romances draws our attention to a mode of narrative production that would erase the subject's specificity. Calling herself Juliet and her lover Romeo, the narrator's individuality would seem to disappear as she attempts to inhabit a universal story of love. Within this standard plot, she becomes simply another tragic heroine, a type. Her final flight to Venice marks one last and desperate attempt to make this romance plot work for her. But Juliet cannot make this love story fit. Hers is not a story of tragic lovers torn apart by a family feud. While their respective interests and associates certainly clash, Juliet and Romeo will nonetheless survive their affair. Instead, Juliet consciously rejects this plot in order to tell another story; she leaves Italy and the romance story behind, returning to England and the alternative story of the feminist collective. Her return to the feminist narrative marks a moment of purposive adaptation. The feminist's story cannot be told through conventional plotlines such as romance. Instead, the feminist chooses the group, accepting and adapting to a social formation of subjectivity. But her conscious decision to choose the group also makes this new narrative possible. In The Type-Writer Girl, the feminist narrative tells the 
story of a heroine's social conscience and also her rejection of standard romance narrative. The feminist subject thus plays an active or purposive role in the formation of the group and its new narrative.

The novel's concluding reference to debt further emphasizes the interdependent relationship between the narrator and the social conditions of reproduction. In the closing lines, Juliet informs readers that she plans to earn money by selling her novel so that she might pay back her loan. But whether her story will be a success, whether readers will accept it, remains to be seen. The only conclusion she can give us is uncertainty: "if this book succeeds I mean to repay Michaela. Meanwhile, in any case, I am saving up daily every farthing to repay her. For I am still a type-writer girl - at another office" (139; ch. 21). Juliet's very narrative started with and now ends with that return to social consciousness. Her final lines of text refuse to resolve her debt to Michaela, choosing instead to leave it open. But it is important to note that this vision of debt is much larger than a personal loan from Michaela, for we must remember that Michaela represents to Juliet that larger category, "womanhood." Juliet's decision to sacrifice romance in order to work for and pay back Michaela represents, by extension, her larger debt to womankind. This makes sense when we think of Juliet's earlier economic bonds with fellow typists: Juliet has always worked on behalf of and in the interest of the feminine group. Her debt to Michaela just represents another variation of her bond with the feminist collective.

Juliet's debt also shows how, through purposive adaptation, the individual might even rewrite the social conditions of self production. By saying that she is still a "type-writer girl," Juliet signals that she remains committed to her feminist ideals and, in particular, the idea of gendered labor (139; ch. 21). But this self-applied moniker also indicates her effort to carve out a space for women's specificity within the marketplace. Moreover, the self-application of the title "girl" reminds us of Juliet's shift in class consciousness following her bond with Elsie. By the novel's end, Juliet proudly refers to herself as a type-writer "girl," not "Lady," a distinction which is reinforced by the book's title. By calling herself "girl," Juliet signals her membership within a larger and classless category of women's work. But Juliet, in turn, does not disappear behind the technologies of mechanical reproduction; rather, even the title, The Type-Writer Girl, calls attention to this gendered aspect of women's work and, therefore, wrestles the feminine out from behind the keys. Rather than obfuscate the female author, this title signals the advent of a new, feminist tale of the uneasy tension between gender and technologies of production.

By the end, we know how to interpret both the novel's complicated title and, by extension, the gestures of end-orientation contained within its opening paragraphs. This title itself should tell us to read that opening scene as setting up a story of self-discovery that will culminate not in an autonomous author but in a story of a "girl's" relationship with gender and the conditions of production. We recall that opening scene in which our narrator introduces herself as a nameless - even genderless - twenty-two year old, "without employment" fighting for survival in a world of "undeciphered faces of men and women." When read in connection with the title "The Type-Writer Girl," this opening scene suggests that the problem of gender difference is absolutely connected with the quest for work. As confirmed by the novel's ending, the narrator will not only find employment, but she will also find her gender and, more importantly, her feminist identity. She will learn to tell the difference between men and women, and this recognition will inspire our heroine's fierce commitment to bonds between women. 
Because this is a novel about the feminist group, it is appropriate that Juliet's story remains unfinished. Both Ann Ardis and Sally Ledger have made convincing arguments about late-Victorian feminists' need to disrupt and thus leave open conventional narratives. These New Women novels end with the dystopian because their heroines exceed the conventional plots and, as such, are still trying to find their ending. Juliet's novel likewise searches for an ending. Her final words, "if this book succeeds," refuse any notion of finality or even certainty. It is this gesture of "what if" that then pushes the text back at us, calling attention to a kind of dialogue between the text and readers. This dialogue makes us, like Juliet, subjects of a social narrative. By leaving the ending unresolved, the novel asks us, the readers, to imagine possible finales for Juliet and the feminist collective. Clarissa J. Suranyi argues that "the reader is comforted by the knowledge that, whatever happens, Juliet Appleton can take care of herself" (16). However, we must remember that Juliet's story is part of a larger narrative about the feminist group, and that story is on-going and can indeed trace its legacy from second- and third-wave innovations back to these earliest pioneers, New Women radicals in the nineteenth century. Juliet's story will remain open and subject to the intervention of many more feminists. And we are still, in the twenty-first century, indebted to the "Juliet Appeletons" and still looking to see if her "book will succeed."

\section{Concordia University (Montreal)}

\section{NOTES}

1. According to Morton, the novel was never published under the author's real name during Allen's lifetime.

2. Allen used the feminine pseudonym "Olive Pratt Rayner" to sign the published version of the novel, further encouraging the assumption that the text is penned by a woman.

3. This equation of the typist with animal echoes Juliet's earlier encounter with a young clerk who "ran his eyes over me as if I were a horse for sale" (30; ch. 2).

4. Juliet's determination to adapt herself to her environment, however, seems more in keeping with a progressive notion of functionalism rather than the Darwinian idea of variation or imperfect adaptation.

5. Atchison explains how Allen was particularly drawn to Spencer's application of biological evolution to social organizations, and how Allen felt that late-nineteenth-century thinkers failed to recognize Spencer's rightful place among the great scientists. For another example of how Allen applied Social Darwinism to the New Woman question, see my essay on The Woman Who Did.

6. See also Gagnier, who explains how Spencer "biologized the division of labor, calling it the law of organic process - consisting in the change from the homogeneous or simple to the heterogeneous, complex, unique, or individuated" (317).

7. To herself, she muses on her own utopian ideal wherein individuals are free to determine their own course of actions and regulation: "In the Utopia I had framed for myself, every man (or woman) did that which was right in his own eyes - without prejudice to his equal freedom to do that which was wrong, if he chanced to be so minded" ( 47 ; ch. 5). Although Allen does use parentheses around "woman" here, my essay discusses how Juliet's story refuses to limit women to such parenthetical representation.

8. Throughout the novel, such advertisements always add alongside "typist" the word "female," with the latter enclosed in parentheses (see ch. 2, pages 28, 29, 30, 32, and 33; ch. 3, pages 37 and 79; and ch. 11). 
9. Such a representation of middle-class feminism is not uncommon in New Women literature at the fin de siècle. For example, in Gissing's Odd Women Mary Barfoot and Rhoda Nunn begin a typewriting business designed to train all of those surplus but, importantly, middle-class women. They deliberately exclude poor and working class women from their social project. For more on the class dynamics in New Women literature, see Langland and Ledger.

10. This process of identification conforms to Adam Smith's notion of sympathy outlined in The Theory of Moral Sentiments. Sympathy, for Smith, describes the human being's ability to imagine or project himself herself in the position of another human being to experience. This act of imagination is so powerful that we can feel the victim's pain upon torture: "By the imagination we place ourselves in his situation, we conceive ourselves enduring all the same torments, we enter as if it were into his body, and become in some measure the same person with him" (Smith 9). As Smith adds, this experience can be too much for one to bear: "Persons of delicate fibers and a weak constitution of body complain, that in looking on the sores and ulcers which are exposed by beggars in the streets, they are apt to feel an itching or uneasy sensation in the corresponding part of their own bodies" (10).

11. As Allen rationalizes, women are bound by biology to carry and to suckle their offspring, and therefore natural biology dictates that "the burden of sex" must fall "much heavier on the female" (168).

12. Allen makes this argument in other essays such as "The Girl of the Future," "Plain Words on the Woman Question," and "Falling in Love."

13. As suggested by Allen's argument with Ward, women's role in sexual selection and social evolution was a popular topic among late-Victorian / Edwardian thinkers. Allen was not alone in his rather ambivalent stand towards New Women's sexual agency within this process. Others, including H. G. Wells (Ann Veronica), Olive Schreiner (Woman and Labor), and George Egerton (Keynotes), insisted on giving the power of sexual selection to women.

14. Given its social contingency, it is no surprise, then, that this reform narrative can at times take a very ugly - even racist - turn. Take, for example, the scene where Juliet notes with horror what she characterizes as the leader Léon's grotesque features: "I think he must have been built after designs by Mr. Aubrey Beardsley. He had rufous hair, a nose without a bridge, and thick protruding lips. Those lips were a nightmare. I set him down as a judicious cross between a Swiss crétin and an albino negro" (50; ch. 6).

15. Juliet consciously decides to ask Michaela as opposed to Romeo for this financial loan. Juliet tells herself that "[t]o borrow from Romeo was now clearly impossible" (136; ch. 21). Instead, Juliet decides to ask Michaela for the money, and in the process of this request, Juliet reminds Michaela of their history of good credit between each other: "I borrowed from you once and repaid you faithfully; if I borrow from you again I will repay in like manner" (138-39).

16. Other elements of the autobiographical narrative include occasion / coaxer, the addressee, and patterns of knowing (see Smith and Watson, ch. 3). One can find all of these elements in The Type-Writer Girl. Juliet addresses the reader, telling us that the occasion (coaxer) for her narrative is her intent to repay her debt (to Michaela / the female collective). And, in many ways, her narrative appeals to familiar patterns of self-inquiry, including the bildungsroman and the adventure romance. However, the elements most relevant to The Type-Writer Girl's innovations in narrative structure and subject center on the different autobiographical "I"s, and so I focus on those elements for that reason.

17. See Keep's two essays, as well as Olwell's and Price's.

18. For another example of the typewriter girl and the spread of a dehumanizing mechanical reproduction, see Wicke's analysis of Dracula where she explains the odd symmetry between technologies of reproduction, including Mina's typewriter, and Dracula: the "social force most analogous to Count Dracula's . . is none other than mass culture, the developing technologies of the media in its many forms" (469).

19. According to Price, Allen was extremely anxious over the rising literary market and its threat to artistic creativity or originality. The first-person, autobiographical tone of the narrative is part of Allen's effort to infuse Juliet with artistic originality and authorial or individual depth. 
20. We know our heroine is headed for a similar fate, a clash between female rivals, when the next chapter is titled "I play Carmen" (ch. 9).

21. For more on the relational subject of autobiography, see Smith and Watson.

22. For more on how the typical autobiographical narrative pushes towards the revelation of the unified and singular subject, see Lejeune.

\section{WORKS CITED}

Allen, Grant. "Falling in Love." 1886. Falling in Love, with Other Essays on More Exact Branches of Science. London: Smith, Elder, 1889. 1-17.

-."The Girl of the Future." Universal Review 7 (May 1890): 49-64. Microfilm Early British Periodical Series, reel 317 [Ball State U].

- "Plain Words on the Woman Question." Fortnightly Review 52 (October 1889): 448-58. Microfilm History of Women, reel 499, no. 3789.1 [U of Notre Dame].

. The Woman Who Did. Ed. Nicholas Ruddick. Peterborough: Broadview, 2004.

. "Woman's Place in Nature." Woman Who Did. Ed. Nicholas Ruddick. Peterborough: Broadview, 2004. 167-68.

- . [as Olive Pratt Rayner] The Type-Writer Girl. Ed. Clarissa J. Suranyi. Peterborough: Broadview, 2004.

Ardis, Anne. New Women, New Novels: Feminism and Early Modernism. New Brunswick: Rutgers UP, 1990.

Atchison, Heather. “Grant Allen, Spencer and Darwin.” Greenslade and Rodgers 55-64.

Benjamin, Walter. "The Work of Art in the Age of Mechanical Reproduction." Illuminations: Essays and Reflections. Ed. Hannah Arendt. New York: Schocken Books, 1968. 217-42.

Cameron, S. Brooke. "Grant Allen's The Woman Who Did: Spencerian Individualism and Teaching New Women to Be Mothers." English Literature in Transition 51.3 (Sept. 2008): 281-301.

Doane, Mary Ann. "Technophilia: Technology, Representation, and the Feminine." Body / Politics: Women and the Discourses of Science. Ed. Mary Jacobus, Evelyn Fox Keller, and Sally Shuttleworth. New York: Routledge, 1990. 163-76.

Eakin, Paul John. How Our Lives Become Stories: Making Selves. Ithaca: Cornell UP, 1999.

Egerton, George. Keynotes. London: Elkin Matthews \& John Lane, 1893.

Ernst, Sabine. "The Woman Who Did and 'The Girl Who Didn't': The Romance of Sexual Selection in Grant Allen and Ménie Muriel Dowie." Greenslade and Rodgers 81-94.

Gagnier, Regenia. "The Law of Progress and the Ironies of Individualism in the Nineteenth Century." New Literary History 31.2 (2000): 315-36. Web. 24 March 2011.

Greenslade, William, and Terence Rodgers. "Resituating Allen: Writing, Radicalism and Modernity." Greenslade and Rodgers 1-22.

Greenslade, William, and Terence Rodgers, eds. Grant Allen: Literature and Cultural Politics at the Fin de Siècle. Burlington: Ashgate, 2005.

Keep, Christopher. "Blinded by the Type: Gender and Information Technology at the Turn of the Century." Nineteenth Century Contexts 23.1 (2001): 149-73. Web. 24 March 2011.

—. "The Cultural Work of the Type-Writer Girl." Victorian Studies 40.3 (1997): 401-26. Web. 24 March 2011.

Langland, Elizabeth. Nobody's Angels: Middle-Class Women and Domestic Ideology in Victorian Culture. Ithaca: Cornell UP, 1995.

Ledger, Sally. The New Woman: Fiction and Feminism at the fin de siècle. Manchester: Manchester UP, 1997.

Lejeune, Philippe. On Autobiography. Minneapolis: U of Minnesota P, 1989. 
Morton, Peter. "The Busiest Man in England”: Grant Allen and the Writing Trade, 1875-1900. New York: Palgrave MacMillan, 2005.

Olwell, Victoria. "Typewriters and the Vote." Signs 29.1 (2003): 55-83. Web. 24 March 2011.

Price, Leah. "Grant Allen's Impersonal Secretaries: Rereading The Type-Writer Girl." Greenslade and Rodgers 129-42.

Randolph, Lyssa. “'The Romance of Race': Grant Allen's Science as Cultural Capital.” Greenslade and Rodgers 65-80.

Rayner, Olive Pratt, see Grant Allen.

Schreiner, Olive. Woman and Labor. 7th ed. New York: Frederick A. Stokes, 1911.

Smith, Adam. The Theory of Moral Sentiments. Ed. D. D. Raphael and A. L. Macfie. New York: Oxford UP, 1976.

Smith, Sidonie, and Julia Watson. Reading Autobiography: A Guide for Interpreting Life Narratives. Minneapolis: U of Minnesota P, 2001.

Spencer, Herbert. Principles of Sociology. London: Williams and Norgate, 1876.

_. "The Social Organism." Essays: Scientific, Political, \& Speculative. Vol. 1. London: Williams and Norgate, 1873.

- Social Statistics: or, the Conditions Essential to Human Happiness Specified, and the First of them Developed. London: John Chapman, 1851.

Spencer, Herbert, et al. Descriptive Sociology; Or, Groups of Sociological Facts. London: Williams and Norgate, 1873. 265-307.

Suranyi, Clarissa J. Introduction, The Type-writer Girl. Peterborough: Broadview, 2004. 9-17.

Ward, Lester Frank. Dynamic Sociology: or Applied Social Science as Based Upon Statical Sociology and the Less Complex Sciences. New York: D. Appleton, 1883.

Wells, H. G. Ann Veronica. London: T. Fisher Unwin, 1909.

Wicke, Jennifer. "Vampiric Typewriting: Dracula and Its Media." ELH 59.2 (Summer 1992): 467-93. Web. 24 March 2011. 